\title{
Assessing the quality of information provided on websites selling Kratom (Mitragyna speciosa) to consumers in Canada
}

\author{
Jeremy Y. $\mathrm{Ng}^{*}$ (D), Muhammad Ans and Amn Marwaha
}

\begin{abstract}
Background: Amid a Canadian opioid crisis, many have turned to natural health products, such as kratom (Mitragyna speciosa), to manage their opioid withdrawal. Kratom has also been reported to relieve anxiety, improve stamina, and heighten physical performance. Given that kratom is not authorized for sale by Health Canada, many have turned to online retailers to purchase kratom due to its easy accessibility online. This study investigated the quality of consumer health information provided on the websites of online vendors selling kratom to consumers in Canada.
\end{abstract}

Methods: Following searches on Google.ca using search terms designed to simulate the information-seeking behaviour of a typical patient-user online, eligible websites were assessed using the 16-question DISCERN instrument, a tool designed to assess the quality of consumer health information. Searches were conducted on March 27, 2020 and only websites presenting information in English were included.

Results: A total of 200 webpages were identified; after screening based on eligibility criteria and combining different webpages that belonged to the same website, 51 websites were found to be eligible. The mean summed DISCERN score across all 51 websites was 36.95 ( $S D=2.44$ ) out of 75, which reflects poor quality consumer health information across the subset of websites. The overall quality of websites was poor, as $78 \%(n=40)$ of vendors received a score of 2 or less out of 5.

Conclusions: Individuals who seek information about kratom online are frequently exposed to poor quality consumer health information. Those looking to purchase kratom online are not provided with the critical information necessary to make an informed decision regarding its use, such as the complete details about the risks and side effects or a description of how kratom affects the body. Given the growing interest in kratom, knowledge of the quality of information available can lead to improved dialogue between healthcare providers and patients.

Keywords: DISCERN, Herbal, Kratom, Online vendor, Mitragyna speciosa, Natural health products, Healthcare professionals

\footnotetext{
*Correspondence: ngjy2@mcmaster.ca

Department of Health Research Methods, Evidence, and Impact, Faculty of Health Sciences, McMaster University, Michael G. DeGroote Centre for Learning and Discovery, Room 2112, 1280 Main Street West, Hamilton, ON L8S 4K1, Canada
}

C C The Author(s). 2021 Open Access This article is licensed under a Creative Commons Attribution 4.0 International License, which permits use, sharing, adaptation, distribution and reproduction in any medium or format, as long as you give appropriate credit to the original author(s) and the source, provide a link to the Creative Commons licence, and indicate if changes were made. The images or other third party material in this article are included in the article's Creative Commons licence, unless indicated otherwise in a credit line to the material. If material is not included in the article's Creative Commons licence and your intended use is not permitted by statutory regulation or exceeds the permitted use, you will need to obtain permission directly from the copyright holder. To view a copy of this licence, visit http://creativecommons.org/licenses/by/4.0/. The Creative Commons Public Domain Dedication waiver (http://creativecommons.org/publicdomain/zero/1.0/) applies to the data made available in this article, unless otherwise stated in a credit line to the data. 


\section{Background}

Canada is in the midst of an opioid crisis; over 15,000 Canadians have lost their lives in opioid-related deaths from 2016 to 2019 [1, 2]. Given the severity of the opioid crisis, many individuals have turned to alternative therapies, including natural health products as they are commonly considered to be safer alternatives by the average consumer [3, 4]. Health Canada defines natural health products as naturally occurring substances that are used to restore or maintain good health and divide them into the following six categories: vitamins and minerals; herbal remedies; homeopathic medicines; traditional medicines such as traditional Chinese medicine or Ayurveda; probiotics; and other products, such as amino acids and essential fatty acids [5]. Kratom (Mitragyna speciosa) is one herbal natural health product commonly used to remedy opioid withdrawal, improve stamina, increase sexual performance, and/or relieve anxiety and chronic pain [6-8]. Despite the potential benefits, kratom is also associated with side effects including skin discoloration, constipation, and weight loss $[9,10]$. Kratom is also used recreationally by some to achieve a euphoric high, and such individuals may do so without consulting or seeking supervision from a qualified healthcare professional [3-5]. Others may be using kratom for perceived health-related benefits.

Kratom is a tropical evergreen tree indigenous to Thailand, Malaysia, Myanmar, and Papua New Guinea, where it has commonly and historically been used as an herbal medicine [10]. Although kratom is indigenous to these aforementioned East Asian nations, today kratom products are produced and distributed in many other countries across the world. Kratom is available to consumers in various forms including pills, capsules, powder, and leaves [11]. Kratom contains multiple psychoactive alkaloids, all of which are naturally occurring [12]. Two main active compounds are mitragynine and 7- $\alpha$-hydroxymitragynine, which interact with opioid receptors in the central nervous system to produce sedative effects and decrease sensitivity to pain $[13,14]$. The most abundant compound is mitragynine, which makes up approximately $66 \%$ of its alkaloid content [13]. In contrast, $7-\alpha$-hydroxymitragynine only makes up $0.02 \%$ of kratom by mass [14, 15]. Although mitragynine is more abundant than 7- $\alpha$-hydroxymitragynine in kratom by mass, $7-\alpha$-hydroxymitragynine is far more potent because it has an affinity for opioid receptors that is 46 times that of mitragynine [16]. The exact mechanism through which kratom alkaloids interact with opioid receptors is still unknown [16]. It is important to note that due to the diversity of alkaloids present in kratom, it possesses both stimulant and opiate-like properties [13, 17]. At lower dosages, kratom may demonstrate stimulative effects, but at higher dosages, opiate-like properties are thought to be predominant $[13,17]$. Other research reveals kratom's potential to alleviate pain without the addictive characteristics akin to opioids currently used for pain management, such as codeine [14]. With respect to the safety profile of kratom, current reports suggest that deaths caused by kratom are usually in association with other substances or due to underlying health issues [18-20]. Some of these substances include fentanyl, heroin, and other prescription opioids [21]. Despite its use for various purposes, an absence of evidence supports the many purported benefits of kratom [7, 17, 22]. Much of the information available about kratom is based on anecdotal reports, user experiences, and case studies [19]. As of September 2020, several trials studying kratom pharmacokinetics were registered on ClinicalTrials. gov, a database of privately and publicly funded clinical trials conducted across the world [23], however, none have been completed or published to date [23]. Due to the possible risks associated with kratom, it is not present on the United States Food and Drug Administration's (FDA) Generally Recognized as Safe list, but it is included in the FDA Poisonous Plant Database. Kratom is legal in Canada provided that it is not used for human consumption [24, 25], however, many vendors are still selling kratom that appears to be intended for consumption, while stating that the product is for "education and research purposes" or for aromatherapy [26, 27]. Kratom, therefore, remains readily available and easily accessible to consumers through online vendors [35]. As individuals in Canada increasingly consult the internet to seek medical advice, self-diagnose, or selfmedicate with products such as kratom, it is crucial to understand the quality of consumer health information provided by vendor websites [28]. Although some individuals may use kratom for non-health purposes (i.e. recreationally), the objective of this study is to assess the quality of consumer health information provided on the websites of online kratom vendors which sell their products to consumers in Canada.

\section{Methods}

\section{Search strategy and screening}

Searches terms were developed by JYN and conducted on Google.ca (Canada), the most popular search engine among internet users [29]. Google was the sole search engine used for this study because it holds over $90 \%$ of the search engine market share in Canada [29]. Searches were conducted by a research assistant on March 27, 2020 using simple search terms designed to simulate the information-seeking behaviour of a typical patient-user online. The complete list of search terms were as follows: "buy kratom online", "buy mitragyna speciosa", "purchase kratom online", and "purchase mitragyna speciosa online". The search was conducted using Google 
Chrome in incognito mode to ensure that the websites retrieved were not influenced by previous search histories.

\section{Eligibility criteria}

MA and AM reviewed the results from the first 5 Google search pages which were included for each search term, as preliminary searches found that subsequent results largely yielded websites that already appeared in earlier search pages. Following deduplication, websites were deemed eligible if they were written in English, and belonged to an online vendor that sold kratom in any form (i.e. powders, capsules, and extracts) to at least one Canadian region. Furthermore, these websites had to provide consumer health information about kratom. Websites that solely provided information about kratom, but did not sell kratom, such as encyclopedia entries, news outlets and social media pages, were ineligible. Major e-commerce websites selling kratom products (i.e. Amazon and Alibaba) were excluded, as these websites did not specifically focus on distributing kratom products. Websites advertised by Google were also excluded because they were not based on search popularity. Lastly, websites with inactive domains were also excluded.

\section{Data extraction and website quality assessment}

MA and AM extracted the following information from each eligible website: website URL, website type (e-commerce, blog, vendor), website name, and types of products sold. Additionally, the quality of consumer health information about kratom presented on each eligible website was assessed using the DISCERN instrument [30]. For the purpose of this study, we collapsed different webpages from the same website into a single item to be quality assessed.

The DISCERN instrument was specifically chosen to assess the subset of websites captured by this study because of its focus on evaluating consumer health information [30]. While it is acknowledged that not all individuals seeking to purchase kratom seek to use it for health-related purposes (i.e. recreational use), the specific aim of our study was to evaluate the quality of consumer health information provided on these websites. Assessing this specific information in our subset of websites using the DISCERN instrument allowed us to evaluate the quality of consumer health information provided by these online kratom vendors. The instrument consists of 15 key questions and an overall rating question (question 16) divided into three sections, each of which evaluates a source of consumer health information (i.e., website) based on a specific quality criterion. Section 1 is designed to evaluate the reliability of the source of consumer health information, whereas section
2 focuses on the specific details about treatment choices. Section 3 asks the assessor to provide an overall evaluation of the quality of information provided by the source of consumer health information. Responses to all questions are assessed based on a 5-point Likert scale ranging from one (lowest quality) to five (highest quality). Model examples of passages reflective of different scores are provided in the DISCERN handbook to assist the rater in assessing the source of consumer health information [28].

To standardize the data extraction process, JYN, MA, and AM conducted a pilot test of the DISCERN instrument, by assessing the consumer health information on three separate websites. All three authors then met and discussed any discrepancies across each item, to standardize the use of the instrument in assessing the subset of websites included in this study. MA and AM extracted the aforementioned data from, and applied the DISCERN instrument, to each eligible website individually and in duplicate. All three authors then met to discuss and resolve any discrepancies in both data extractions and DISCERN scores, the latter of which without unduly modifying scores. The average of the two assessors' scores were calculated for each question across all websites. This provided an overall summed DISCERN score between 15 and 75, based on the scores for the first 15 questions. The average score and standard deviation were calculated for each DISCERN question and the overall summed DISCERN score. All data were collected and analyzed using Microsoft Excel.

\section{Results}

\section{Search results}

A total of 200 webpages were extracted from the first 5 pages of each search strategy. After screening for duplicates, 100 webpages were excluded. Of the remaining 100 webpages, 41 were excluded for the following reasons: did not sell kratom $(n=11)$, did not ship to Canada $(n=8)$, invalid URL $(n=8)$, e-commerce website $(n=6)$, not published in English $(n=3)$, news outlet $(n=3)$, a social media page $(n=1)$, and a Wikipedia article $(n=1)$. A further 8 webpages belonging to the same websites were collapsed into a single item. The remaining 51 websites were deemed eligible and assessed with the DISCERN instrument. This process is depicted in Fig. 1.

\section{General characteristics of eligible websites}

Sixty-one percent (31 out of 51) of websites exclusively sold kratom products, while $29 \%$ (15 out of 51 ) of websites also sold other herbal products such as cannabidiol, turmeric, and herbal teas. No websites discussed any conventional therapies, such as pharmaceutical medications or surgery. A common feature among websites 


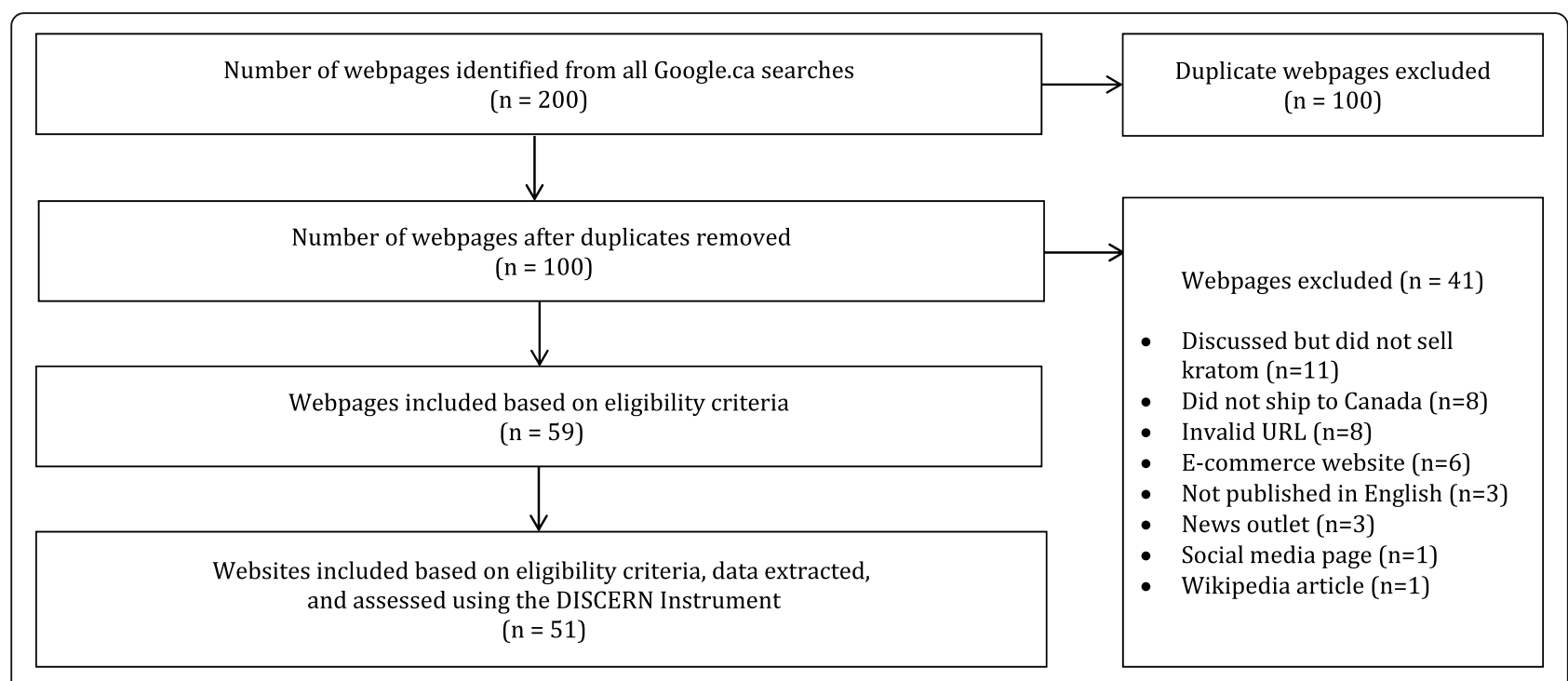

Fig. 1 Web Information Search Strategy and Assessment Flowchart

were the inclusion of blogs and news sections addressing topics such as the benefits, risks, legality, user experience, and biochemical interactions of kratom. Fortyseven percent (24 out of 51) of websites stated that their kratom products were solely for research purposes, not for human consumption. The general characteristics of all eligible websites assessed using the DISCERN instrument are presented alphabetically in Table 1 .

\section{DISCERN instrument ratings}

The average summed DISCERN score across all 51 websites was $36.95(\mathrm{SD}=2.44)$ out of 75 . This score is representative of the poor quality of consumer health information available on these websites. Of the first 15 questions, only question 1 (if the aims were clearly stated) and question 2 (if the aims were achieved), had a total mean score greater than 3 (out of 5) across all websites; all other questions had a total mean score of less than 2.5. DISCERN scores for each question of each website are presented in Table 2, listed in descrneding order of summed DISC ERN score.

\section{Trends identified across resources assessed}

\section{SECTION 1 is the publication reliable? (questions 1-8)}

Questions 1 and 2 assessed if the aims of the website were clearly stated and if those aims were achieved, respectively. The questions that received the highest total mean scores were question 1 that scored 4.16 $(\mathrm{SD}=1.10)$ and question 2 that scored $4.16(\mathrm{SD}=$ 1.10). Websites with higher scores on questions 1 and 2 generally had a separate page explaining their aim which often included information about the type of product being sold, the origin of the product, and the location of the distributor. Question 3 assessed the relevance of the consumer health information present on the website. The presence of information that was relevant to different types of consumers, such as pregnant women, seniors, and adolescents, was evaluated in this question. This question received the lowest total mean score of $1.37(\mathrm{SD}=0.54)$, with all of the websites scoring a 2.5 or less. Websites that received relatively higher scores examined some risks to different types of consumers. However, many retailers lacked a sufficient explanation of the risks of kratom to potentially at-risk consumers. These websites advised consumers to consult a healthcare provider before consuming kratom products, in cases such as when pregnant or nursing. Question 6 assessed whether the information presented on the website was balanced and unbiased. The websites received a mean score of 1.92 with $84 \%$ (43 out of 51 ) of them receiving an average score of less than 3 . This score reflects the fact that many websites presented questionable information or promotional material on their website. Sixteen percent (8 out of 51) of websites achieved a rating of 3 or higher and used sources such as peer-reviewed literature or government websites to support their claims. Question 8 examined whether the website made mention of any uncertainties associated with the product advertised. These uncertainties pertained to a lack of research on the product, variable side effects and risks of the product, and the legality of the product. Eighty percent (41 out of 51) of the websites scored 2.5 or less on this question. 
Table 1 General Characteristics of Eligible Websites

\begin{tabular}{|c|c|c|c|c|}
\hline Website Name & URL & Types of NHPs Discussed & $\begin{array}{l}\text { Other Types of } \\
\text { Products Discussed }\end{array}$ & $\begin{array}{l}\text { Showed Up in More } \\
\text { than One Search? }\end{array}$ \\
\hline Authentic Kratom & $\begin{array}{l}\text { https://www.authentickratom. } \\
\text { com/ }\end{array}$ & Kratom (powders, crushed leaf, incense) & Incense Kit & Yes \\
\hline Azarius & $\begin{array}{l}\text { https://azarius.net/smartshop/ } \\
\text { kratom/ }\end{array}$ & $\begin{array}{l}\text { Kratom (leaves, extracts, capsules, tinctures, } \\
\text { powders), cacti, kanna, Salvia divinorum }\end{array}$ & $\begin{array}{l}\text { Vaporizers, ice trays, } \\
\text { playing cards }\end{array}$ & Yes \\
\hline BC Kratom & https://bckratom.com/ & Kratom powder & None & No \\
\hline Best Kratom & https://bestkratom.com/ & Kratom (powders and extracts) & None & Yes \\
\hline Big Bear Kratom & https://bigbearkratom.com/ & Kratom powder & None & No \\
\hline $\begin{array}{l}\text { Botanical } \\
\text { Remedies }\end{array}$ & $\begin{array}{l}\text { https://botanicalremediesllc. } \\
\text { com/ }\end{array}$ & Kratom (powders, extract, capsules) & None & Yes \\
\hline Buy Kratom & https://www.buykratom.com/ & Kratom (powder, capsule) & None & Yes \\
\hline $\begin{array}{l}\text { Buy Kratom Bulk } \\
\text { USA }\end{array}$ & https://buykratombulkusa.com/ & Kratom (powders, capsules, blends) & None & Yes \\
\hline $\begin{array}{l}\text { Buy Kratom } \\
\text { Extracts }\end{array}$ & $\begin{array}{l}\text { https://buy-kratom-extracts. } \\
\text { com/ }\end{array}$ & $\begin{array}{l}\text { Kratom (powder, extract, capsule, liquid and } \\
\text { sleepwalker energy booster) }\end{array}$ & Capsule machine & Yes \\
\hline Cali Botanicals & https://www.calibotanicals.com/ & Kratom (powders, capsules, extract, tincture) & None & Yes \\
\hline $\begin{array}{l}\text { Canada Kratom } \\
\text { Express }\end{array}$ & $\begin{array}{l}\text { https://www. } \\
\text { canadakratomexpress.com/ }\end{array}$ & Kratom (powders) & None & Yes \\
\hline $\begin{array}{l}\text { Canada Kratom } \\
\text { Store }\end{array}$ & $\begin{array}{l}\text { https://www. } \\
\text { canadakratomstore.com/ }\end{array}$ & Kratom (powders) & None & Yes \\
\hline Earth Kratom & https://earthkratom.com/ & Kratom (powder, capsule, extract, blend) & None & No \\
\hline Evergreen Tree & https://theevergreentree.com/ & Kratom (powders, crushed leaf, incense) & Hand sanitizers & Yes \\
\hline EZ Kratom & https://ezkratom.com/ & Kratom (powders and extracts) & None & Yes \\
\hline Flavourz & https://buy-kratom.us/ & Kratom (powder and extract) & None & No \\
\hline Kats Botanicals & https://katsbotanicals.com/ & $\begin{array}{l}\text { Kratom (powders, extracts, stem and vein, } \\
\text { soaps, crushed leaves) }\end{array}$ & None & Yes \\
\hline KayBotanicals & https://kaybotanicals.com/ & $\begin{array}{l}\text { Kratom (powders, extracts, capsules, soaps, } \\
\text { teas), turmeric }\end{array}$ & None & Yes \\
\hline Kraatje & https://www.kraatje.eu/ & $\begin{array}{l}\text { Kratom (powders, extract, capsule, mixes, } \\
\text { tea), moringa, purwoceng powder, tongkat ali }\end{array}$ & None & Yes \\
\hline Kraken Kratom & https://krakenkratom.com & $\begin{array}{l}\text { Kratom (powders, leaves, teas, capsules), } \\
\text { kava tea }\end{array}$ & $\begin{array}{l}\text { Empty capsules, } \\
\text { bathroom scales }\end{array}$ & Yes \\
\hline Kratom Crazy & https://kratomcrazy.com/ & Kratom (powder, capsule) & None & Yes \\
\hline Kratomdudes & https://kratomdudes.com/ & Kratom (powder) & None & Yes \\
\hline Kratom Earth & https://www.kratomearth.com/ & Kratom (powders and extracts) & None & Yes \\
\hline Kratom Exchange & $\begin{array}{l}\text { https://www.kratomexchange. } \\
\text { com/ }\end{array}$ & Kratom (powders) & None & Yes \\
\hline Kratom Gardens & $\begin{array}{l}\text { https://www.kratomgardens. } \\
\text { com/en/ }\end{array}$ & $\begin{array}{l}\text { Kratom (powders, extract, soaps, crushed leaf), } \\
\text { green tea, maca }\end{array}$ & $\begin{array}{l}\text { Capsule filling machine, } \\
\text { empty capsules }\end{array}$ & Yes \\
\hline Kratom Krates & https://kratomkrates.com/ & Kratom (powder, capsule, cannabidiol) & None & Yes \\
\hline Kratomystic & https://kratomystic.com/ & Kratom (powder, capsules, extract) & None & Yes \\
\hline Kratom of Life & https://kratomoflife.com/ & Kratom (soaps, and incense, candle) & Candles, soap bars & Yes \\
\hline Kratom-Online & $\begin{array}{l}\text { https://www.kratom-online. } \\
\text { com/ }\end{array}$ & Kratom (powders, crushed leaf) & None & Yes \\
\hline Kratomnesia & https://kratomnesia.com/ & $\begin{array}{l}\text { Kratom (powders, blends, and natural herbs, } \\
\text { cocoa powder, red ginger, black pepper, } \\
\text { white pepper) }\end{array}$ & None & Yes \\
\hline Kratora & https://buykratom.us/ & $\begin{array}{l}\text { Kratom (powders, extracts, akuamma seeds, } \\
\text { blue lotus, kanna, sakae naa, kava) }\end{array}$ & Gift certificates & Yes \\
\hline Kratom Spot & https://kratomspot.com/ & Kratom (powders, extract, capsules) & $\begin{array}{l}\text { Accessories and } \\
\text { merchandise }\end{array}$ & Yes \\
\hline
\end{tabular}


Table 1 General Characteristics of Eligible Websites (Continued)

\begin{tabular}{|c|c|c|c|c|}
\hline Website Name & URL & Types of NHPs Discussed & $\begin{array}{l}\text { Other Types of } \\
\text { Products Discussed }\end{array}$ & $\begin{array}{l}\text { Showed Up in More } \\
\text { than One Search? }\end{array}$ \\
\hline Kratom Wave & $\begin{array}{l}\text { https://kratomwave.com/buy- } \\
\text { kratom/ }\end{array}$ & Kratom (powder, tea, capsule, free samples) & None & Yes \\
\hline Left Coast Kratom & https://left-coast-kratom.com/ & Kratom (powders, capsules, extract, tea) & $\begin{array}{l}\text { Kratom handbook, } \\
\text { capsule machine }\end{array}$ & Yes \\
\hline Legal Herbal Shop & $\begin{array}{l}\text { https://www.legalherbalshop. } \\
\text { com/ }\end{array}$ & $\begin{array}{l}\text { Kratom (capsules, powders, crushed leaf, } \\
\text { extracts), cannabidiol }\end{array}$ & $\begin{array}{l}\text { Vaporizes, shisha, herbal } \\
\text { smoking blends }\end{array}$ & Yes \\
\hline $\begin{array}{l}\text { Mitra Genie } \\
\text { Kratom }\end{array}$ & https://mitrageniekratom.com/ & Kratom (capsules, extracts, powders) & None & Yes \\
\hline Moon Kratom & https://moonkratom.com/ & Kratom (powder, liquid extract) & Company merchandise & No \\
\hline Online Kratom & https://onlinekratom.com/ & Kratom (extracts, fusions, capsules) & Merchandise & Yes \\
\hline $\begin{array}{l}\text { Order Kratom } \\
\text { Online }\end{array}$ & https://orderkratomonline.ca/ & Kratom (powder) & None & No \\
\hline $\begin{array}{l}\text { Original Harvest } \\
\text { Kratom }\end{array}$ & $\begin{array}{l}\text { https://www. } \\
\text { originalharvestkratom.com/ }\end{array}$ & Kratom (powders, capsules, leaf extracts) & None & Yes \\
\hline PA Botanicals & https://pabotanicals.com/ & $\begin{array}{l}\text { Kratom (powders, tinctures, capsules, extract, } \\
\text { cannabidiol, kava, akuamma) }\end{array}$ & None & Yes \\
\hline Phoria & https://www.phoriakratom.com/ & Kratom (powder, capsule, extract, topicals) & None & Yes \\
\hline Phytoextractum & $\begin{array}{l}\text { https://www.phytoextractum. } \\
\text { com/ }\end{array}$ & $\begin{array}{l}\text { Kratom (powder, capsules, extract), plant } \\
\text { extracts, materials, tonics, essential oils, } \\
\text { cannabidiol, ethnobotanicals, kava, kombucha, } \\
\text { mushroom, maca, coffee, blue lotus }\end{array}$ & Scales, empty capsules & Yes \\
\hline PurKratom & https://purkratom.com/ & Kratom (capsules and powder) & None & Yes \\
\hline Sacred Kratom & $\begin{array}{l}\text { https://www.sacredkratom. } \\
\text { com/ }\end{array}$ & Kratom (capsules, extract, powder) & None & Yes \\
\hline Super Speciosa & https://superspeciosa.com/ & Kratom (capsules, powder, hemp cannabidiol) & None & No \\
\hline $\begin{array}{l}\text { The IAmShaman } \\
\text { Shop }\end{array}$ & $\begin{array}{l}\text { https://iamshaman.com/default. } \\
\text { htm }\end{array}$ & $\begin{array}{l}\text { Kratom (powder, extract, dried leaf), morning } \\
\text { glory, voacanga, incense, kava, kanna, wild } \\
\text { dagga }\end{array}$ & $\begin{array}{l}\text { Books, burners, } \\
\text { candles, oils }\end{array}$ & Yes \\
\hline $\begin{array}{l}\text { The Kratom } \\
\text { Connection }\end{array}$ & $\begin{array}{l}\text { https://thekratomconnection. } \\
\text { com/ }\end{array}$ & Kratom (powders and capsules) & None & Yes \\
\hline Titan Kratom & https://www.titankratom.com/ & $\begin{array}{l}\text { Kratom (powders, capsules, blends), hawaiian } \\
\text { baby woodrose }\end{array}$ & Vape devices, julls & No \\
\hline True North Kratom & $\begin{array}{l}\text { https://www.truenorthkratom. } \\
\text { com/ }\end{array}$ & Kratom (powder) & None & Yes \\
\hline
\end{tabular}

\section{SECTION 2 how good is the quality of information on treatment choices? (questions 9-15)}

Questions 10 and 11 assessed whether the website correctly identified the benefits and the risks associated with the product, respectively. Thirty-three percent (17 out of 51) of the websites achieved a rating of 3 or higher on question 10; in contrast, only $16 \%$ (8 out of 51 ) of the websites achieved a rating of 3 or higher on question 11. For those websites that identified the risks, they did not do so extensively and only mentioned risks specific to certain consumer populations, such as pregnant women. Otherwise, risks were stated in the form of a legal disclaimer surrounding kratom. Websites that achieved a relatively higher score on both questions 10 and 11 had a section dedicated to examining the benefits and risks of the product. Question 12 assessed whether the website described what would happen if no product was used. All websites achieved a score of 1.5 or lower, as generally minimal to no pertinent information was provided. Question 13 assessed whether the website described how the product may impact the overall quality of life. Ninety-eight percent (50 out of 51 ) of the websites scored 2.5 or less.

\section{SECTION 3 overall rating of the website (question 16)}

Question 16 examined the overall quality of the website as a source of information. Ninety percent (45 out of 51) of websites had an overall score of less than 3 out of 5 . Of the $10 \%$ ( 5 out of 51 ) of websites with a score higher than 2, the highest score was 3.5 out of 5 . The relatively low ratings can be attributed to the lack of information provided by the websites including, but not limited to: biased information, missing references, and minimal mention of uncertainties. Some of the higher scoring 


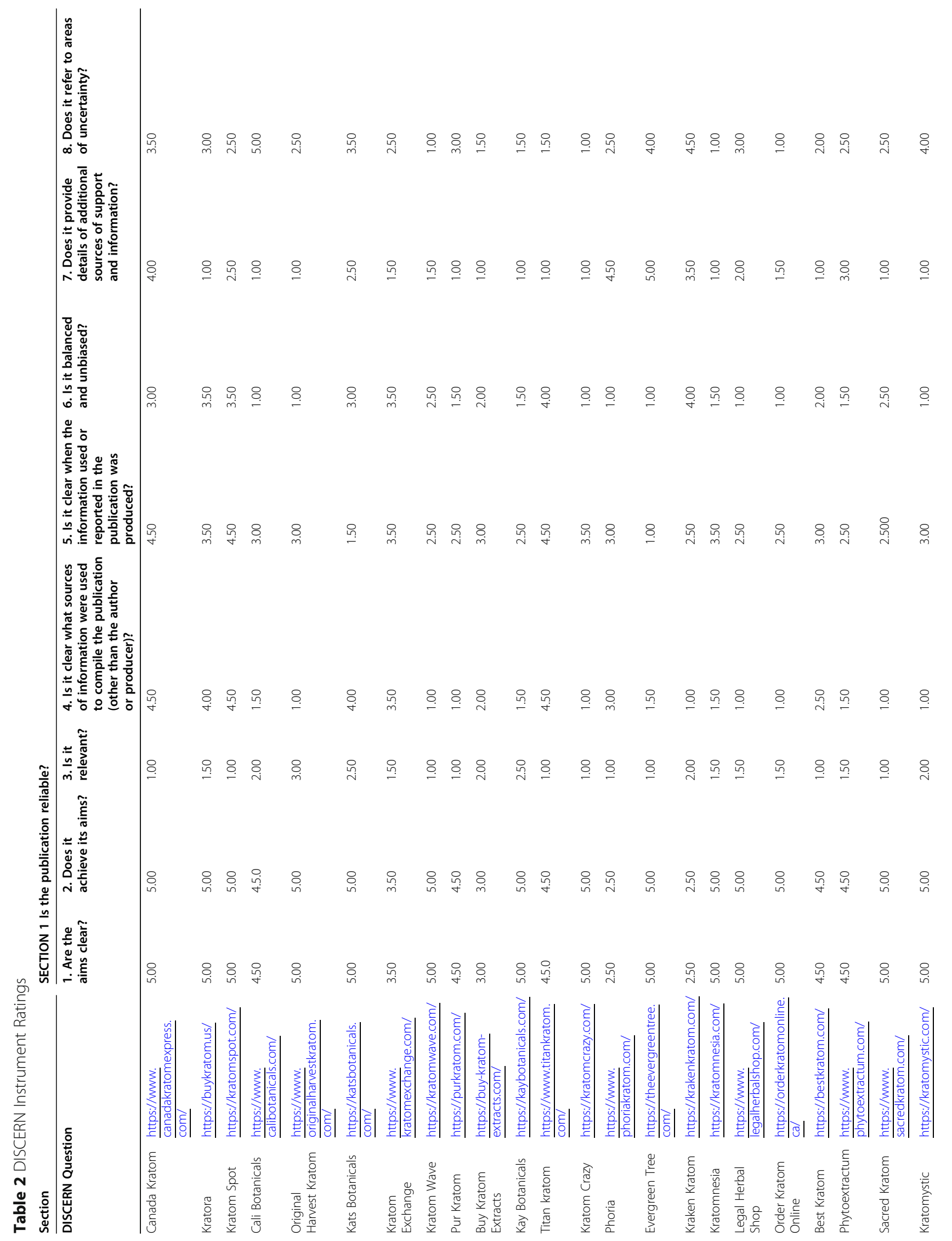




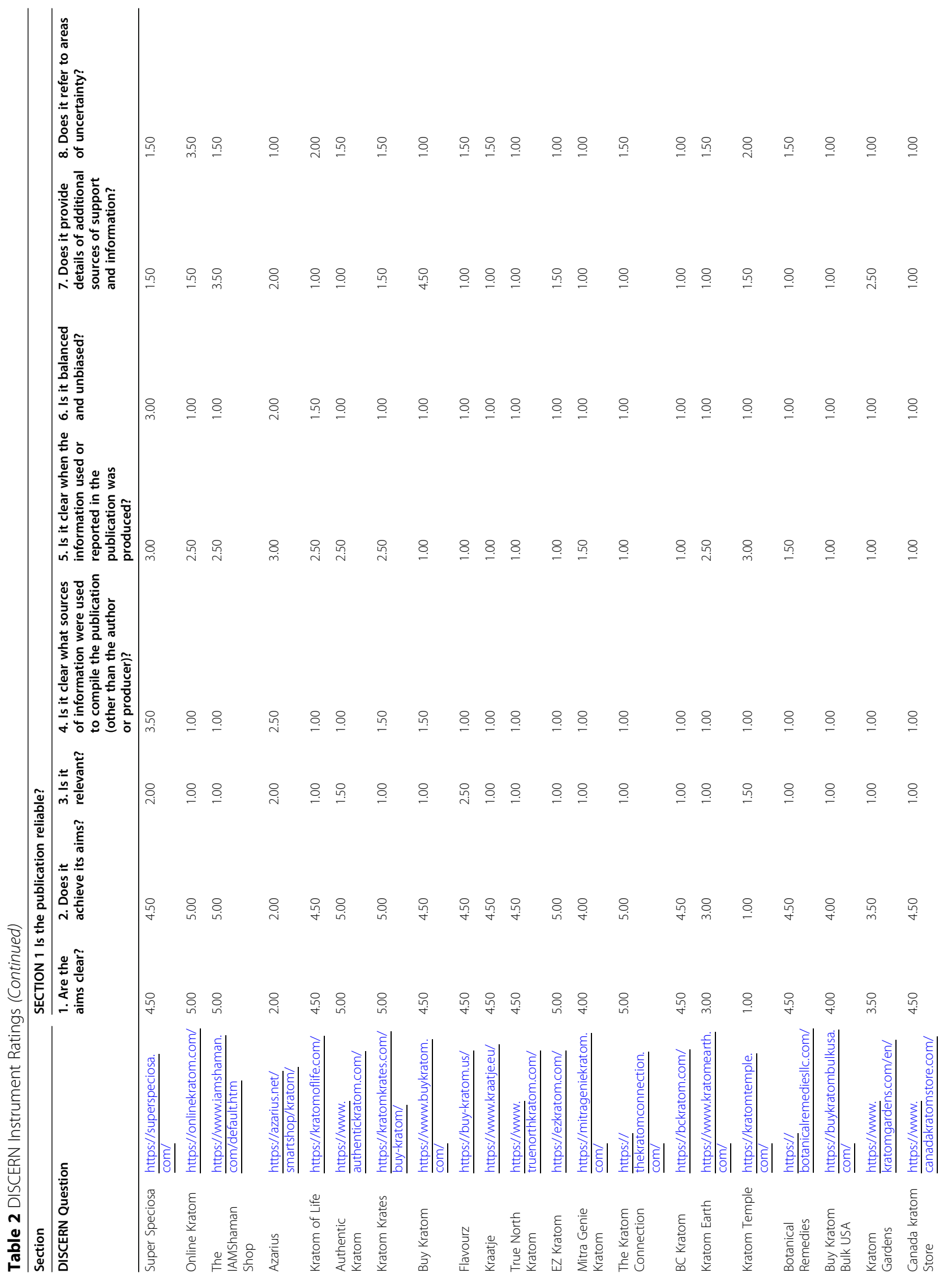




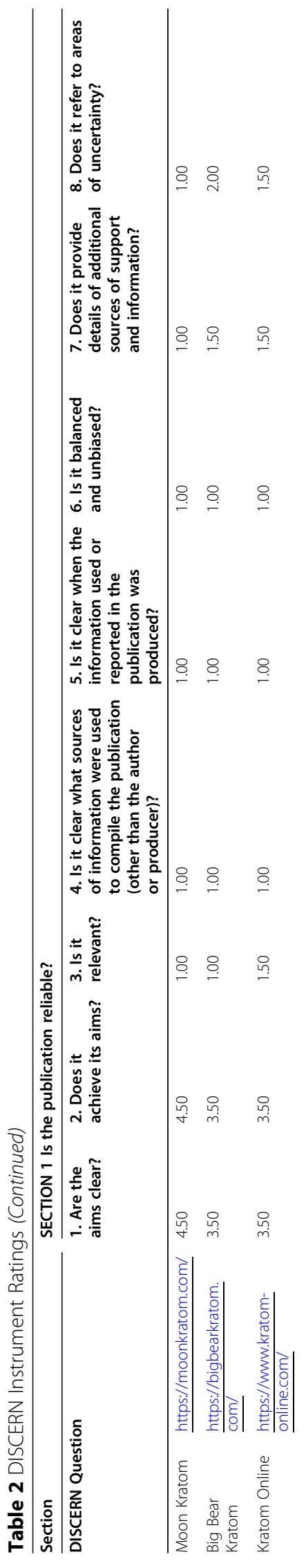




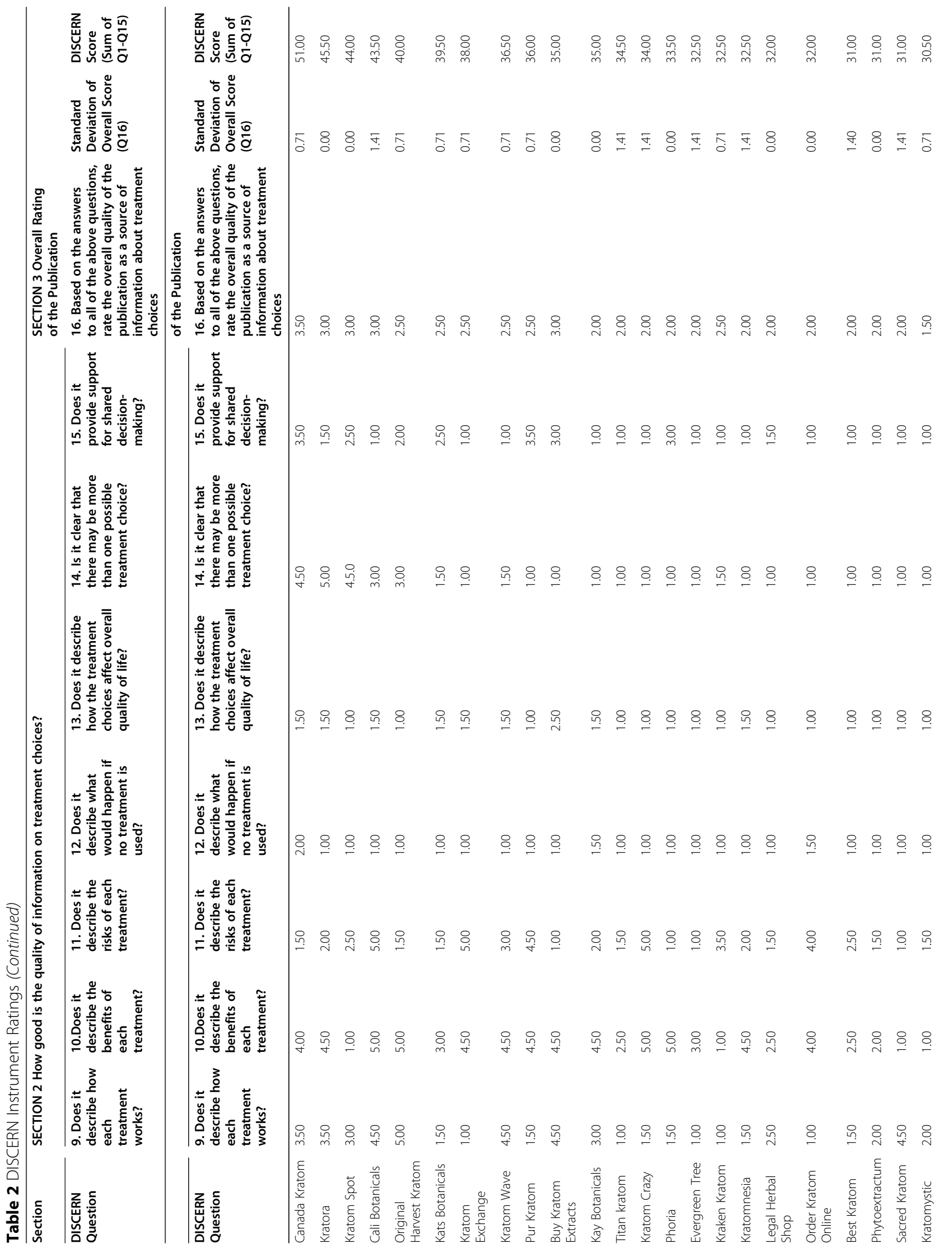




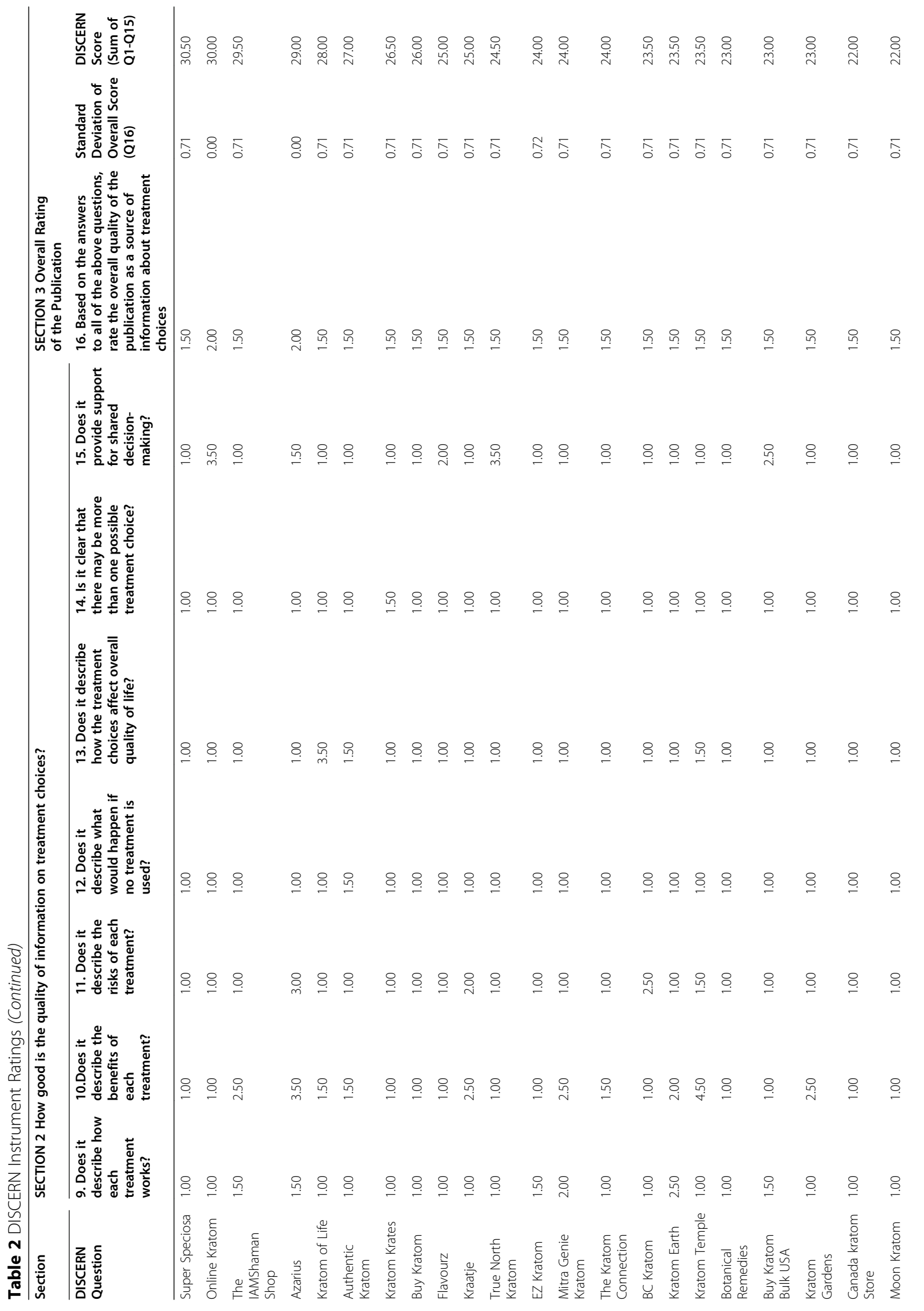




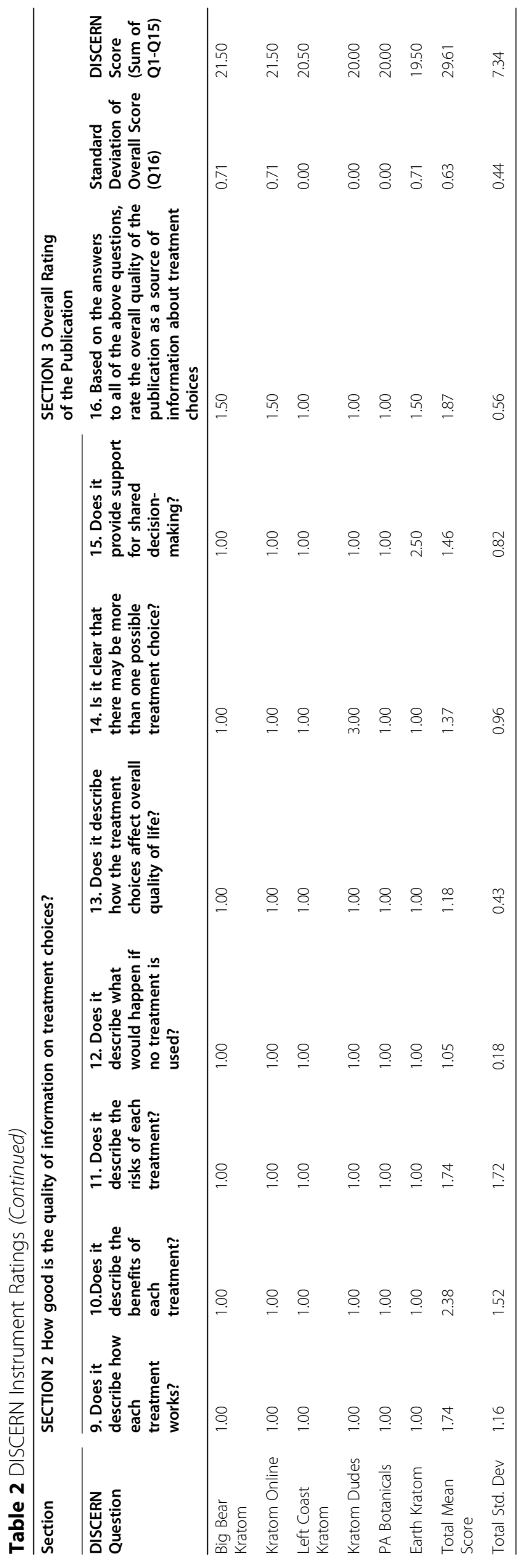


websites included information concerning the benefits, risks, and uncertainties associated with the product.

\section{Discussion}

The present study assessed the quality of consumer health information provided by websites of vendors selling kratom products to consumers in Canada. Although online websites exist to easily facilitate the purchase and consumption of kratom, these online vendors often failed to provide consumers with high-quality consumer health information pertaining to kratom as a suitable product option. The average summed DISCERN score across all 51 websites was $36.95(\mathrm{SD}=2.44)$ out of 75 , which reflects the poor quality of consumer health information. Across all eligible websites, 78\% $(n=40)$ received an overall score (question 16) of 2 or lower, which also indicated that the quality of information present on these websites was poor. This study provides healthcare practitioners with a better understanding of the quality of information currently available to patients with an expressed interest in purchasing kratom. Physicians, among other healthcare providers, may use this information to better counsel their patients about the benefits, risks, and the quality of information surrounding kratom use. These discussions, in turn, may improve patients' abilities to make informed decisions about the purchase and use of kratom.

To our knowledge, this is the first study to focus on assessing the quality of consumer health information provided by websites of online vendors selling kratom products. However, similar investigations have been conducted regarding other herbal remedies which present findings that are comparable to the present study. A similar study assessed the quality of consumer health information presented by online vendors selling Ephedra sinica to consumers in Canada. The results of the study outlined that the majority of the websites failed to present the information necessary to make an informed purchase decision [31]. Another study examined the quality of information present at the intersection of complementary alternative medicine and arthritis. The DISCERN instrument was used to rank the quality of consumer health information, revealing that the subset of websites assessed underreported the risks associated with specific treatment options [32]. Furthermore, a study examined the quality and readability levels of information provided by websites selling herbal supplements marketed as remedies for menopausal symptoms. This study also used the DISCERN instrument to assess the quality of health-related information provided about each product [33]. The results of all three studies were similar as they identified that the quality of consumer health information provided by online sources was poor [31,33] or variable [32].

The poor quality of consumer health information identified across online kratom vendor websites may be explained by their commercial nature. Sharing with consumers that their products are associated with potentially harmful health risks may negatively impact the volume of sales. Thus, such retailers are in a perpetual conflict of interest with respect to providing accurate, high-quality consumer health information [34]. Given a general lack of available high-quality research evidence (i.e. clinical trials) examining the purported benefits of kratom, it is unsurprising that the majority of the websites we assessed provided information about kratom which relied upon personal experiences and historical claims.

With respect to clinical practice, this study's findings suggest the importance of healthcare provider education about kratom. It is necessary that they take a full substance use history including natural products such as kratom, regardless of whether these were bought online or locally by the patient. A warranted direction for future research includes evaluating the accuracy of information provided by online vendors selling kratom to consumers in Canada, as this was beyond the scope of what the DISCERN instrument measures. Evaluating content accuracy will not only provide a better understanding of health-relatedinformation present on the internet, but it can also pinpoint specific factual inaccuracies and errors. An additional future direction can involve conducting a qualitative content analysis of the consumer health information presented on this subset of websites to examine and better understand patterns in communication. Collectively, the results of these additional investigations can further inform healthcare providers about the sources of information their patients may be consulting prior to deciding to purchase and consume kratom. Additionally, healthcare providers can use this information to promote public health initiatives which aim to inform the public about the poor quality of consumer health information pertaining to kratom that is available online.

\section{Strengths and limitations}

A strength of our study includes the fact that we extracted the data and scored the websites independently and in duplicate. Furthermore, we assessed the quality of consumer health information using the DISCERN instrument which has been found to be both reliable and valid for this purpose [30]. We conducted pilot tests prior to completing both the data extraction and DISC ERN questions, followed by a discussion among all three authors to better standardize the data extraction and interpretation process. A limitation of our study may 
include that our results are not necessarily applicable to other jurisdictions, as we specifically focused on online vendors that sold kratom products to consumers in Canada. Furthermore, this study did not assess the content accuracy of the information provided on eligible websites. It should also be acknowledged that the internet is dynamic and online information is constantly changing, therefore our findings are reflective of a single snapshot in time. Lastly, it is acknowledged that an additional limitation includes the assessment of only English language websites due to resource constraints. Assessing websites written in French or in the numerous indigenous languages spoken in Canada could have provided an added layer of findings.

\section{Conclusion}

In light of the ongoing opioid crisis in Canada, kratom is sought by many facing opioid withdrawal as a potential solution, and is easily accessible for purchase and consumption through online vendors. We sought to assess the quality of consumer health information provided on the websites of online vendors that sold kratom products to consumers in Canada. This study found that the quality of information presented across the majority of websites was poor, with many failing to provide sufficient information about the benefits, risks, and uncertainties of kratom needed for consumers to make an informed decision about its purchase and use. Given the increased popularity of this herbal product, this study can further inform healthcare providers about the types of information their patients may be consulting prior to purchasing kratom. It is important that healthcare providers are educated on the topic of kratom, and ensure that they take a full patient substance use history that includes inquiring about kratom. The information from this study can be used to better equip healthcare providers in promoting informed decision making about the use of kratom.

\section{Abbreviation}

FDA: United States Food and Drug Administration

\section{Acknowledgements}

We gratefully acknowledge Ashley Luo for their assistance with data collection.

\section{Authors' contributions \\ JYN: conceptualized and designed the study, collected the data, interpreted and analysed the data, drafted the manuscript, and gave final approval of the version to be published. MA: collected the data, interpreted and analysed the data, provided contributions and critically revised the manuscript, and gave final approval of the version to be published. AM: collected the data, interpreted and analysed the data, provided contributions and critically revised the manuscript, and gave final approval of the version to be published.}

\section{Funding}

JYN was funded by a Research Scholarship and an Entrance Scholarship from the Department of Health Research Methods, Evidence and Impact, Faculty of Health Sciences at McMaster University.
Availability of data and materials

All relevant data are included in this manuscript.

\section{Declarations}

Ethics approval and consent to participate

This study involved a search and review of publicly available online information only; it did not require ethics approval or consent to participate.

\section{Consent for publication}

All authors consent to this manuscript's publication.

\section{Competing interests}

The authors declare that they have no competing interests.

Accepted: 4 March 2021

Published online: 19 March 2021

\section{References}

1. Corkery MJ, Streete P, Claridge H, Goodair C, Papanti D, Orsolini L, Schifano F, Sikka K, Korber S, Hendricks A. Characteristics of death associated with kratom use. J Psychopharmacol. 2019;33(9):1102-23. https://doi.org/10.1177/ 0269881119862530

2. Special Advisory Committee on the Epidemic of Opioid Overdoses. Opioids and stimulant-related Harms in Canada. Ottawa: Public Health Agency of Canada; 2020. https://health-infobase.canada.ca/substance-related-harms/ opioids-stimulants. Accessed 1 Feb 2021

3. Diep J, Chin DT, Gupta S, Syed F, Xiong M, Cheng J. Kratom, an emerging drug of abuse. A A Pract. 2018;10(8):192-4. https://doi.org/10.1213/XAA. 0000000000000658 .

4. Kwan D, Boon HS, Hirschkorn K, Welsh S, Jurgens T, Eccott L, et al. Exploring consumer and pharmacist views on the professional role of the pharmacist with respect to natural health products: a study of focus groups. BMC Complement Altern Med. 2008:8:40. https://doi.org/10.1186/1472-6882-8-40.

5. Canada H. Natural health products. Quick Facts 2020. https://www.canada. $\mathrm{ca} /$ en/health-canada/services/drugs-health-products/natural-nonprescription.html. Accessed 1 Feb 2021.

6. Singh D, Narayanan S, Müller CP, Marc TS, Rahim AA, Abdullah MFILB, et al. Severity of Kratom (Mitragyna speciosa Korth.) psychological withdrawal symptoms. J Psychoactive Drugs. 2018;50:445-50. https://doi.org/10.1080/02 791072.2018.1511879.

7. Stanciu CN, Gnanasegaram SA, Ahmed S, Penders T. Kratom withdrawal: a systematic review with case series. J Psychoactive Drugs. 2019;51(1):12-8. https://doi.org/10.1080/02791072.2018.1562133.

8. Garcia-Remeu A, Cox DJ, Smith KE, Dunn KE, Griffiths RR. Kratom (Mitragyna speciosa): user demographics, use patterns, and implications for the opioid pandemic. Drug Alcohol Depend. 2020;208:107849. https://doi.org/10.1016/ j/drugalcdep.2020.107849.

9. Natural Doesn't Necessarily Mean Safer, or Better. NCCIH n.d. https://www. nccih.nih.gov/health/know-science/natural-doesnt-mean-better. Accessed 1 Feb 2021.

10. Fluyau D, Revadigar N. Biochemical benefits, diagnosis, and clinical risks evaluation of Kratom. Front Psychiatry. 2017;8:62. https://doi.org/10.3389/ fpsyt.2017.00062.

11. Lydecker AG, Sharma A, McCurdy CR, Avery BA, Babu KM, Boyer EW. Suspected adulteration of commercial Kratom products with 7Hydroxymitragynine. J Med Toxicol. 2016;12:341-9. https://doi.org/10.1007/ s13181-016-0588-y.

12. Kruegel AC, Grundmann O. The medicinal chemistry and neuropharmacology of kratom: a preliminary discussion of a promising medicinal plant and analysis of its potential for abuse. Neuropharmacolgy. 2018;134(A):108-20. https://doi.org/10.1016/j.neuropharm.2017.08.026.

13. Váradi A, Marrone GF, Palmer TC, Narayan A, Szabó MR, Le Rouzic V, et al. Mitragynine/Corynantheidine Pseudoindoxyls as opioid analgesics with mu Agonism and Delta antagonism, which do not recruit $\beta$-Arrestin-2. J Med Chem. 2016;59:8381-97. https://doi.org/10.1021/acs.jmedchem.6b00748.

14. Shellard EJ. The alkaloids of Mitragyna with special reference to those of Mitragyna speciosa, Korth. Bull Narc. 1974;26:41-55.

15. Kamble SH, León F, King TI, Berthold EC, Lopera-Londoño C, Siva Rama Raju K, et al. Metabolism of a Kratom alkaloid metabolite in human plasma 
increases its opioid potency and efficacy. ACS Pharmacol Transl Sci. 2020;3: 1063-8. https://doi.org/10.1021/acsptsci.0c00075.

16. Matsumoto K, Mizowaki M, Suchitra T, Murakami Y, Takayama H, Sakai S, et al. Central antinociceptive effects of mitragynine in mice: contribution of descending noradrenergic and serotonergic systems. Eur J Pharmacol. 1996; 317:75-81. https://doi.org/10.1016/s0014-2999(96)00714-5.

17. Kruegel AC, Gassaway MM, Kapoor A, Váradi A, Majumdar S, Filizola M, Javitch AJ, Sames D. Synthetic and receptor signaling explorations of the Mitragyna alkaloids: Mitragynine as an atypical molecular framework for opioid receptor modulators. J Am Chem Soc. 2016;138(21):6754-64. https:// doi.org/10.1021/jacs.6b00860.

18. Holler JM, Vorce SP, McDonough-Bender PC, Magluilo I Jr, Solomon CJ, Levine B. A drug toxicity death involving propylhexedrine and mitragynine. J Anal Toxicol. 2011;35(1):54-9. https://doi.org/10.1093/anatox/35.1.54.

19. Domingo O, Roider G, Stover A. Mitragynine concentrations in two fatalities. Forensic Sci Int. 2017;271:e1-7. https://doi.org/10.1016/j.forsciint.2016.12.020.

20. Olsen EO, O'Donnell J, Mattson CL, Schier JG, Wilson N. Notes from the Field: Unintentional Drug Overdose Deaths with Kratom Detected - 27 States, July 2016-December 2017. Morb Mortal Wkly Rep. 2019;68:326-7. https://doi.org/10.15585/mmwr.mm6814a2externalicon.

21. Corkery JM, Streete P, Claridge H, Goodair C, Papanti D, Orsolini L, et al. Characteristics of deaths associated with kratom use. J Psychopharmacol. 2019;33:1102-23. https://doi.org/10.1177/0269881119862530.

22. Swogger MT, Walsh Z. Kratom use and mental health: a systematic review. Drug Alcohol Depend. 2018;183:134-40. https://doi.org/10.1016/j.druga Icdep.2017.10.012

23. ALL - List Results.-Home - ClinicalTrials.gov. US National Library of Medicine. https://linicaltrials.gov/ct2/results?cond=\&term=kratom\&cntry=\&state= \&city=\&dist $=$. Accessed 1 Feb 2021.

24. Garcia-Romeu A, Cox DJ, Smith KE, Dunn KE, Griffiths RR. Kratom (Mitragyna speciosa): user demographics, use patterns, and implications for the opioid epidemic. Drug Alcohol Depend. 2020;208:107849. https://doi.org/10.1016/j. drugalcdep.2020.107849.

25. Veltri C, Grundmann O. Current perspectives on the impact of Kratom use Subst Abus Rehabil. 2019. https://doi.org/10.2147/SAR.S164261.

26. Unauthorized "Jupiter" and "Kratom Zone" kratom products seized from two Edmonton stores. n.d. https://www.healthycanadians.gc.ca/recall-alert-ra ppel-avis/hc-sc/2017/63746a-eng.php (Accessed 18 Feb 2021).

27. Snowdon W, Fournier A. Kratom: antidote or adversary in Canada's opioid crisis? | CBC news: CBC; n.d. https://www.cbc.ca/news/canada/ edmonton/kratom-drug-alberta-edmonton-canada-herbal-1.4185789. Accessed 1 Feb 2021

28. Tonsaker T, Bartlett G, Trpkov C. Health information on the internet: gold mine or minefield? Can Fam Physician. 2014;60:407-8.

29. Search Engine Market Share Canada. StatCounter Global Stats. https://gs.sta tcounter.com/search-engine-market-share/all/canada. Accessed 1 Feb 2021.

30. Charnock D. The DISCERN handbook: quality criteria for consumer health information; user guide and training resource. Abingdon: Radcliffe Medical Press; 1998. http://www.discern.org.uk/discern.pd

31. Ng JY, Marwaha A, Ans M. The quality of information available about Ephedra sinica on online vendor websites: the Canadian consumer experience. Complement Ther Med. 2021;27:102674.

32. Ng JY, Vacca A, Jain T, Ng JY, Vacca A, Jain T. The quality of online consumer health information at the intersection of complementary and alternative medicine and arthritis. Adv Rheumatol. 2021;61. https://doi.org/1 0.1186/s42358-021-00162-y

33. Sowter J, Astin F, Dye L, Marshall P, Knapp P. Assessment of the quality and content of website health information about herbal remedies for menopausal symptoms. Maturitas. 2016;88:16-22. https://doi.org/10.1016/j. maturitas.2016.02.016.

34. Mayan M, Kutt A, Punja S, Bienko I, Vohra S. Interprofessional undergraduate health sciences students' experiences seeking natural health product information from Canadian vendors as self - described in reflective essays. Eur J Integr Med. 2018;20:182-7. https://doi.org/10.1016/j.eujim.2018.05.007.

\section{Publisher's Note}

Springer Nature remains neutral with regard to jurisdictional claims in published maps and institutional affiliations.

Ready to submit your research? Choose BMC and benefit from:

- fast, convenient online submission

- thorough peer review by experienced researchers in your field

- rapid publication on acceptance

- support for research data, including large and complex data types

- gold Open Access which fosters wider collaboration and increased citations

- maximum visibility for your research: over $100 \mathrm{M}$ website views per year

At BMC, research is always in progress.

Learn more biomedcentral.com/submissions 